\title{
Diet and feeding activity of Acestrorhynchus lacustris (Lütken, 1875) (Characiformes, Acestrorhynchidae) in the water reservoir at Ribeirão Claro, SP
}

\author{
Silva, AT.* and Goitein, R.* \\ Departamento de Zoologia, Instituto de Biociências, Campus Rio Claro, Universidade Estadual Paulista - UNESP \\ Av. 24A, 1515, Bairro Bela Vista, CEP 13506-900, Rio Claro, SP, Brazil \\ *e-mail: silva.at@gmail.com, rgoitein@rc.unesp.br \\ Received April 23, 2007 - Accepted June 21, 2007 - Distributed August 31, 2009
}

(With 3 figures)

\begin{abstract}
A. lacustris is a widely distributed species in the São Francisco and Paraná river basins, mainly in lentic waters. Specimens were captured monthly, over a whole year in a reservoir built by damming the Ribeirão Claro stream (SP). The stomach contents analyses showed a predominantly piscivorous diet. Feeding activity showed to be clearly less intense during winter, when all the sampling groups were compared. Despite the fact that the diet of A. lacustris presents a high diversity of prey-species, the prey size, their abundance and also behavior possibly determined a certain preference for some of them.
\end{abstract}

Keywords: Acestrorhynchus lacustris, peixe-cachorro, diet, feeding activity, fish.

\section{Dieta e atividade alimentar de Acestrorhynchus lacustris (Lütken, 1875) (Characiformes, Acestrorhynchidae) no reservatório de captação de água do Ribeirão Claro, SP}

\begin{abstract}
Resumo
O peixe cachorro, Acestrorhynchus lacustris, encontra-se amplamente distribuído nas bacias do rio São Francisco e do alto rio Paraná, sobretudo nos locais de caráter lêntico. Ao longo de um ano, foram capturados mensalmente exemplares desta espécie no reservatório de captação de água do Ribeirão Claro. A análise do conteúdo estomacal dos exemplares capturados revelou uma dieta predominantemente piscívora. Durante o inverno, foi constatada uma diminuição acentuada da atividade alimentar do peixe-cachorro. Apesar de apresentar uma diversidade relativamente alta de espécies-presa, foi observada certa predileção por algumas, cujo tamanho, abundância e comportamento, foram os prováveis fatores determinantes.
\end{abstract}

Palavras-chave: Acestrorhynchus lacustris, peixe-cachorro, dieta, atividade alimentar e peixes.

\section{Introduction}

Fish feeding studies constitute important surveys, as they are a way of knowing how the energy flows inside a system where the fish species lives, and they permit one to evaluate how a species maintains, grows and reproduces in the system (Wootton, 1992; Zavala-Camin, 1996). As well as that, fish feeding studies permit one to interpret what kind of trophic relationships an aquatic system sustains (Hahn et al., 1997a; Zavala-Camin, 1996) and help environmental conservation purposes. (Pompeu and Godinho, 2003). Wootton (1992) states that feeding studies should be held for at least one year in order that individuals of a population in all the seasons reveal their life cycle and how their diet is influenced by the biotic and abiotic conditions of the system.

Acestrorhynchus lacustris (Lütken, 1875) (Figure 1) is a characoid of the family Acestrorhynchidae. This is

a neotropical species whose individuals are widely distributed in the São Francisco river basin and also in the high Paraná basin (Menezes, 1992). It is neglected for commercial purposes and individuals are very common in lakes. On the other hand, it is an important species for the fish food chain (Hahn et al., 2000). When reservoirs are constructed, foraging species become very abundant and $A$. lacustris, as a piscivorous species, is used to control their proliferation (Agostinho, et al., 1992). Some fish may stabilize this situation inside an ecosystem by their carnivorous habit, regulating the population size of the prey species (Nikolskii, 1963; Popova, 1978). They are also called "biological cleaners", due to the fact that they eliminate the sick or weak individuals of the population prey species (Popova, 1978). Simon (1983) also 
considers that predators are important to maintain natural communities healthy by removing old and weak individuals, which are the most available to them.

Feeding of Acestrorhynchus lacustris has been studied by other authors. In other aquatic systems (Almeida et al., 1997; Hahn et al., 2000; Gomes and Verani, 2003; Pompeu and Godinho, 2003), consisting of larger rivers than the stream where this study was carried out. A study in such a small stream over a whole year more clearly shows distinctions, as distinct seasons also cause a considerable difference of the water level, which may influence the food availability for this species.

\section{Material and Methods}

\subsection{The State area}

The Ribeirão Claro stream (Figure 2) arises near to the city of Ajapi and its drainage area is located in a region constituted by low hills at an altitude of about

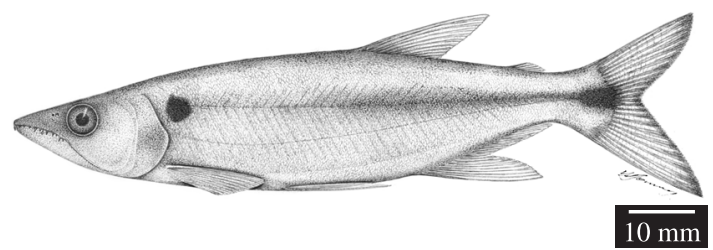

Figure 1. Acestrorhynchus lacustris (Lütken, 1875) (Characiformes, Acestrorhynchidae). Artist: Jaime Somera.

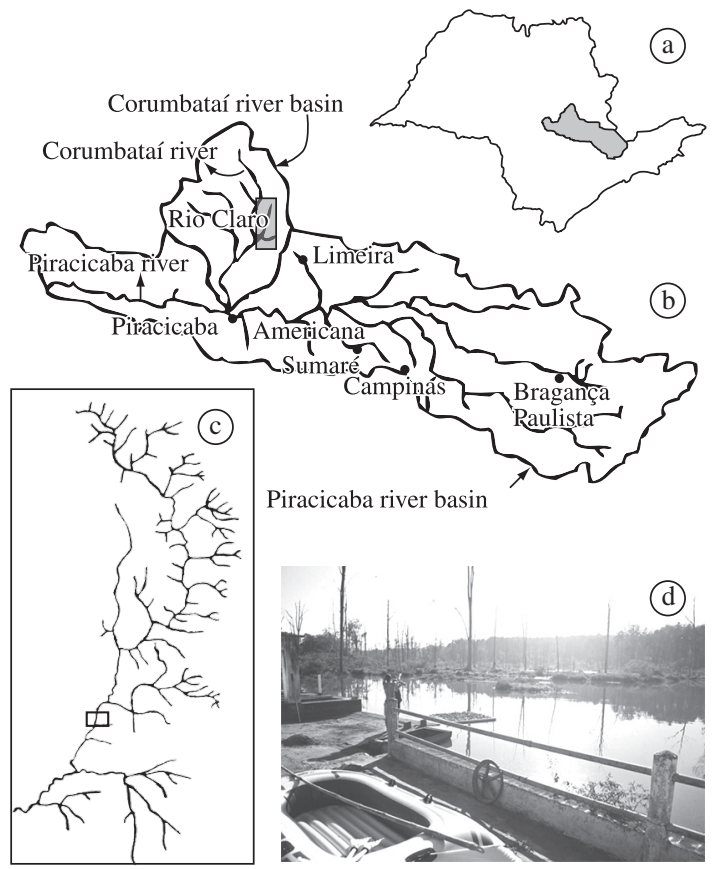

Figure 2. a) The Piracicaba river basin in São Paulo State; b) the Ribeirão Claro stream in the Corumbataí Basin; c) the studied area in Ribeirão Claro; and d) water reservoir in Ribeirão Claro.
$700 \mathrm{~m}$. It passes through the urban perimeter of Rio Claro before its waters flow into the Corumbataí River. The reservoir from which about $50 \%$ of the water consumed by Rio Claro is taken, is relatively near that town. It is a semi-lentic system (Camargo, pers. comm.) attaining a maximum depth of about $2 \mathrm{~m}$. Following Köppen's classification, the area shows the Cwa type climate, which means subtropical with a winter dry season and a rainy one in summer. Temperatures in January vary from 20 to $27.7{ }^{\circ} \mathrm{C}$, and during July they vary from 14.9 to $17.1^{\circ} \mathrm{C}$.

\subsection{Data collection}

Twelve monthly samplings were made starting in July 2003. Their data were then put together in four groups, following the collection times, and were denominated as follows: winter (July-September), spring (October-December), summer (January-March) and autumn (April-June). Collections were made using five gill-nets (mesh distances between adjacent knots: 1.5; $2.0 ; 2.5 ; 3.0$ and $3.5 \mathrm{~cm}$ ), each of them measuring $10 \mathrm{~m}$, and totalizing $50 \mathrm{~m}$ in extension. The gill nets were put in place during 24 hours, starting at noon, and examined every three hours. The fishes were maintained in ice to be transported to the laboratory, only a few kilometres distant from the collection site, and kept in a freezer until analysis. The standard length in ( $\mathrm{mm})$ and total weight (g) of the individuals were measured. Sexes were identified and the total mass of food contents was also measured. Stomachs containing food were then conserved in a $70 \%$ ethanol solution.

\subsection{Data analyses}

The stomach contents were analyzed using the Occurrence Frequency Method (F\%) (Hyslop, 1980), Volumetric Analysis Index (Lima-Jr and Goitein, 2001) and the Food Importance Index (AI) (Lima-Jr and Goitein, 2001). The feeding among distinct sampling groups was compared using the Spearman Ranking Comparison Test (Fritz, 1974).

The feeding activity was evaluated using the Stomach Repletion Index (IR) (Hyslop, 1980). The results obtained for each sampling group were compared to each other, using the Kruskall-Wallis Test (significance level of 0.05) (Zar, 1999).

\section{Results}

During the period 228 specimens were caught. From these, 42 were caught during winter, 55 during spring, 61 during summer and 70 during autumn. They were only caught using gill nets whose mesh distances varied from 1.5, 2.0 and 2.5. Of all the individuals, only 49 (21.5\%) presented food in their stomachs.

This fish showed a highly predominant piscivorous diet. Food categories were established in order to permit a diet comparison among the distinct year phases (Table 1). The categories referring to fish (Characidae, Curimatidae, Cichlidae, Gymnotidae and non-identified fish) were predominant during the whole period. 
Table 1. Occurrence frequency (F\%) and Feeding Importance Index (AI) for each feeding category in each sampling group. The values inside parentheses show the relative values of AI for each sampling group. (-) absence of a category in the sampling group.

\begin{tabular}{|c|c|c|c|c|c|c|c|c|}
\hline \multirow[t]{2}{*}{ Feeding categories } & \multicolumn{2}{|c|}{ Winter } & \multicolumn{2}{|c|}{ Spring } & \multicolumn{2}{|c|}{ Summer } & \multicolumn{2}{|c|}{ Autumn } \\
\hline & F\% & AI & F\% & AI & $\mathrm{F} \%$ & AI & $\mathbf{F} \%$ & AI \\
\hline Curimatidae & - & - & 7.14 & $\begin{array}{c}267.86 \\
(0.02)\end{array}$ & 6.25 & $\begin{array}{c}561.52 \\
(0.06)\end{array}$ & 5.56 & $\begin{array}{c}358.80 \\
(0.06)\end{array}$ \\
\hline Characidae & 50 & $\begin{array}{c}1250.00 \\
(0.44)\end{array}$ & 50 & $\begin{array}{c}12410.71 \\
(0.83)\end{array}$ & 18.75 & $\begin{array}{c}322.27 \\
(0.04)\end{array}$ & 33.33 & $\begin{array}{c}3240.74 \\
(0.50)\end{array}$ \\
\hline Cichlidae & 50 & $\begin{array}{c}1562.50 \\
(0.56)\end{array}$ & - & - & - & - & - & - \\
\hline Gymnotidae & - & - & - & - & - & - & 5.56 & $\begin{array}{c}34.72 \\
(0.005)\end{array}$ \\
\hline Non-identified fish & - & - & 42.86 & $\begin{array}{c}2219.39 \\
(0.15)\end{array}$ & 68.75 & $\begin{array}{c}7841.80 \\
(0.89)\end{array}$ & 61.11 & $\begin{array}{c}2800.93 \\
(0.44)\end{array}$ \\
\hline Insects & - & - & 7.14 & $\begin{array}{c}6.38 \\
(0.0004)\end{array}$ & - & - & - & - \\
\hline Vegetable material & - & - & 21.43 & $\begin{array}{c}114.80 \\
(0.01)\end{array}$ & 12.5 & $\begin{array}{c}39.06 \\
(0.004)\end{array}$ & - & - \\
\hline Sediment & - & - & - & - & 6.25 & $\begin{array}{c}4.88 \\
(0.0005)\end{array}$ & - & - \\
\hline
\end{tabular}

Characidae, mainly represented by Astyanax altiparanae Garutti and Britski 2000, Hyphessobrycon eques (Steindachner, 1882) and Serrapinnus spp., constituted the dominant category, being followed by non-identified fishes and then the Curimatidae [Cyphocarax modestus (Fernández-Yépez, 1948)]. The remaining categories presented low importance values, suggesting they were casually ingested. A more detailed description of the food categories and their distribution during all the sampling groups may be seen in Table 2 .

The statistic test used to compare the diet in distinct sampling groups did not show significant differences among them (Table 3). However, some small variations happened to occur when fish categories were ranked. The winter sampling was excluded from this analysis due to the fact that a very low feeding activity was registered in that sampling group, from which only two stomachs presented some food. During spring, the main food was represented by characids.

Non-identified fish predominated in the summer samples, being followed by curimatids and characids. The autumn sample was represented mainly by characids and non-identified fish.

The feeding activity showed to be clearly less intense during winter when sampling groups were compared (Figure 3). The other phases showed to be similar in this aspect.

\section{Discussion}

Bennemann et al. (1996) have observed a piscivorous feeding habit for A. lacustris. The same was observed by Hahn et al. (2000), Gomes and Verani (2003) and Pompeu and Godinho (2003). They all observed that fish constitutes the diet of the species. Some other authors observed the presence of insects and plants, however, as occasional items in the composition of the species diet (Catella and Torres, 1984; Mesquiatti, 1995; Almeida et al., 1997). All these results serve to reinforce what has been observed in this study.

Non-identified fish, as a category, presented some expressive AI values, which is to be expected, as fish are usually rapidly digested. During summer, this category showed an even more elevated contribution, possibly due to the fact that at higher temperatures the digesting process accelerates, thus making difficult the identification of this kind of food.

When it was possible to identify the food item, the species Astyanax altiparanae, and Cyphocarax modestus were clearly dominant for the larger individuals, whereas Hyphessobrycon eques and Serrapinnus spp. constituted the main food for the smaller ones (pers. obs.). Other authors (Almeida et al., 1996; Hahn et al., 2000; Gomes and Verani, 2003) observed that Astyanax and curimatids constituted the main food items of Acestrorhynchus lacustris.

Hahn et al. (2000) described as opportunistic the feeding habit of this species, as its diet consisted of 17 fish species, which should be the available ones at distinct moments. It should also be considered that this study was held in a much larger river, which at the time, had been recently dammed, and in such a case many distinct species should be available as a kind of artificial consequence of this situation. Even in such a case, the two main prey-species were relatively abundant in the system during the whole period, mainly $C$. modestus, but A. altiparanae predominated as the food item for A. lacustris. For this study very small individuals of C. modestus were rarely caught, but, on the other hand, 
Table 2. Occurrence of feeding categories for each sampling group. Items were registered in detail when possible.

\begin{tabular}{|c|c|}
\hline \multicolumn{2}{|l|}{ Winter } \\
\hline Feeding category/ Specie & Popular name \\
\hline CHARACIDAE & Mato-grosso \\
\hline $\begin{array}{l}\text { Hyphessobrycon eques } \\
\text { (Steindachner, 1882) }\end{array}$ & \\
\hline CICHLIDAE & Cará \\
\hline $\begin{array}{l}\text { Geophagus brasiliensis } \\
\text { (Quoy and Gaimard, 1824) }\end{array}$ & \\
\hline \multicolumn{2}{|l|}{ Spring } \\
\hline Feeding category/ Specie & Popular name \\
\hline \multicolumn{2}{|l|}{ CHARACIDAE } \\
\hline $\begin{array}{l}\text { Astyanax altiparanae } \\
\text { Garutti and Britski, } 2000\end{array}$ & Tambiú \\
\hline $\begin{array}{l}\text { Acestrorhynchus lacustris } \\
\text { (Lütken, 1875) }\end{array}$ & Peixe-cachorro \\
\hline $\begin{array}{l}\text { Hyphessobrycon eques } \\
\text { (Steindachner, 1882) }\end{array}$ & Mato-grosso \\
\hline Serrapinus sp. & \\
\hline \multicolumn{2}{|l|}{ CURIMATIDAE } \\
\hline $\begin{array}{l}\text { Cyphocharax modestus } \\
\text { (Fernández-Yépez, 1948) }\end{array}$ & Saguiru \\
\hline \multicolumn{2}{|l|}{ Non-identified fish } \\
\hline \multicolumn{2}{|l|}{ Insects } \\
\hline Vegetable material & Seeds \\
\hline
\end{tabular}

Table 3. Comparison between sampling groups using the rank correlation coefficient of Spearman. (Significance level of 0.05).

\begin{tabular}{ccccl}
\hline $\begin{array}{c}\text { Sampling } \\
\text { groups } \\
\text { compared }\end{array}$ & $\begin{array}{c}\text { Number } \\
\text { of } \\
\text { categories }\end{array}$ & $\mathbf{R}$ & $\mathbf{p}$ & Results \\
\hline $\begin{array}{c}\text { Spring } \times \\
\text { summer }\end{array}$ & 8 & 0.531 & 0.176 & $\begin{array}{l}\text { Similar } \\
\text { diets }\end{array}$ \\
$\begin{array}{c}\text { Spring } \times \\
\text { autumn }\end{array}$ & 7 & 0.748 & 0.532 & $\begin{array}{l}\text { Similar } \\
\text { diets }\end{array}$ \\
$\begin{array}{c}\text { Summer } \times \\
\text { autumn }\end{array}$ & 6 & 0.638 & 0.173 & $\begin{array}{l}\text { Similar } \\
\text { diets }\end{array}$ \\
\hline
\end{tabular}

small individuals of A. altiparanae were commonly found and they should be potentially ingested by A. lacustris. The mesh selectivity of the gill nets used to catch the fish species for this study was also inspected (Silva, unpublished data), and permitted the possibility of it to retain small individuals of $C$. modestus as well. Moreover, the gill nets were positioned in several distinct ways, such as the proximities of marginal aquatic vegetation and open waters. So, sampling method failures should be excluded as an explanation for the absence of small individuals of $C$. modestus in that place and they should be less fre-
Table 2. Continued...

\begin{tabular}{|c|c|}
\hline \multicolumn{2}{|l|}{ Summer } \\
\hline Feeding category/ Specie & Popular name \\
\hline \multicolumn{2}{|l|}{ CHARACIDAE } \\
\hline $\begin{array}{l}\text { Hyphessobrycon eques } \\
\text { (Steindachner, 1882) }\end{array}$ & Mato-grosso \\
\hline Serrapinus sp. & \\
\hline CURIMATIDAE & Saguiru \\
\hline \multicolumn{2}{|l|}{$\begin{array}{l}\text { Cyphocharax modestus } \\
\text { (Fernández-Yépez, 1948) }\end{array}$} \\
\hline \multicolumn{2}{|l|}{ Non-identified fish } \\
\hline Vegetable material & Leaves \\
\hline \multicolumn{2}{|l|}{ Sediment } \\
\hline \multicolumn{2}{|l|}{ Autumn } \\
\hline Feeding category/ Specie & Popular name \\
\hline \multicolumn{2}{|l|}{ CHARACIDAE } \\
\hline $\begin{array}{l}\text { Astyanax altiparanae } \\
\text { Garutti and Britski, } 2000\end{array}$ & Tambiú \\
\hline $\begin{array}{l}\text { Hyphessobrycon eques } \\
\text { (Steindachner, 1882) }\end{array}$ & Mato-grosso \\
\hline Serrapinus sp. & \\
\hline \multicolumn{2}{|l|}{ CURIMATIDAE } \\
\hline $\begin{array}{l}\text { Cyphocharax modestus } \\
\text { (Fernández-Yépez, 1948) }\end{array}$ & Saguiru \\
\hline \multicolumn{2}{|l|}{ GYMNOTIDAE } \\
\hline $\begin{array}{l}\text { Gymnotus carapo } \\
\text { Linnaeus, } 1758\end{array}$ & Tuvira \\
\hline Non-identified fish & \\
\hline
\end{tabular}

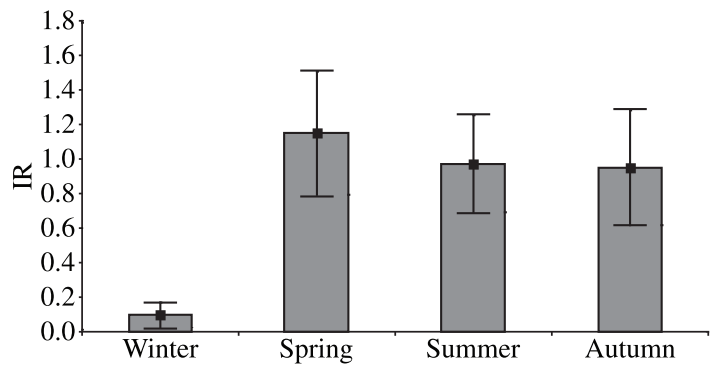

Figure 3. Mean and mean standard error of the stomach repletion indices (IR) calculated for the fish caught in each sampling group. Kruskal Wallis test: $\mathrm{H}=8.629, \mathrm{gl}=3$, $\mathrm{p}<0.05$.

quent there. As Almeida et al. (1997) state, the prey size is one of the factors influencing its choice as food. Hahn et al., (2000) proposes a size limit of fishes to be ingested by a predator species. Such a limitation may explain the fact that smaller individuals of A. lacustris fed mainly on H. eques and Serrapinnus spp., a species represented by small individuals. Some other authors say that prey species should in general attain no more than one third of the size (standard length) of the predator. Goulding et al. (1988) and Machado-Allison (1990) have registered that piscivorous fishes in the Negro River in Amazonas and 
Venezuela eat fishes whose length attains less than one third of themselves (33.33\%). Catella and Torres (1984) found similar results of $A$. lacustris in the Santa Maria Reservoir on the São Francisco River.

Another hypothesis refers to the foraging behavior of $A$. lacustris, as well as that presented by its main prey. Hahn et al. (2000) reported that the species usually pursues its prey, an expected fact shown by the presence of caniniform and conical teeth, added to its characteristic mouth in which the inclined position of the jaw suggests a food uptake from the water column. This feature may reflect its preference by A. altiparanae, which usually forages at the water column, an already described behavior for other species of the genus (Uieda, 1984). Other fish presenting such a habit were also found as components of the species diet (Hyphessobrycon eques, Serrapinnus spp., A. lacustris). The fact does not exclude the possibility of the species exploiting the bottom of the system, as some sediment was also found among the stomach contents. Besides, some fishes known to live near the bottom were also found in the stomach contents of A. lacustris, such as the acará Geophagus brasiliensis Sabino and Castro (1990) and the C. modestus (Sazima and Caramaschi, 1989). In any case, the prevailing observations show a diet consisting of prey species that usually live mainly in the water column.

An elevated number of empty stomachs is normally expected to occur when piscivorous species are studied. The same fact is usually found to happen with Salminus maxillosus (Esteves and Pinto-Lobo, 2001), for Hoplias malabaricus (Barbieri et al., 1982, Winemiller, 1989) and for Plagyoscion squamosissimus (Hahn et al., 1997b). In the Tibagi River only $23.5 \%$ of the individuals of A. lacustris presented some food in their stomachs (Bennemann et al., 1996). Barbieri et al. (1982) state that piscivorous species usually present a low feeding activity, a fact to be explained due to the relatively elevated nutritional composition of their diet, and also to the fact they must pursue the prey species (Nikolskii, 1963). Winemiller (1989) states that the low frequent feeding activity of carnivorous fish species may be explained by the fact they take a longer time to digest a compact food like a fish before they start a new feeding activity. This should not be a motivation, as herbivorous fishes take even longer to digest their food, a fact that explains their relatively long intestines. Concentrated energy present in the food should explain better the less frequent feeding activity common to piscivorous fishes, which in turn are used to swallowing big fish pieces at once (Bennemann et al., 1996).

The results show a less intense feeding activity of A. lacustris during winter, when temperatures were lower. This should be the cause of a lower feeding activity, and not the absence of potential prey, because such species abundance in the system was almost the same during that season, when compared to the other ones, and their reproductive cycle would start during spring (Bazzoli and Godinho, 1991). Zavala-Camin (1996) confirms that some fish species usually diminish their feeding activity under low temperatures, as a lower digestive process may cause less appetite for the fish.

In general, A. lacustris presented a predominantly piscivorous diet, feeding on a relatively high diversity of fishes. However, the prey size, their abundance and also the behavior possibly determined a certain preference for some of them (H. eques, Serrapinnus spp., A. altiparanae and $C$. modestus). In this context, as this is an abundant species in that environment, it plays a role in the maintenance of that community structure, by controlling the population sizes of the foraging species, which otherwise would be much more abundant in such an altered place.

Acknowledgements - We are grateful to FAPESP, the sponsors of this study (Proc. 04/02285-3); to IBAMA for the specimens capture authorization (Proc. 02027.01665/03-55); to everyone who helped in the field work, especially Carolina Cappi, Alberto L. Carmassi, Michel Metran, Paul F. C. Rosas, Gabriel Cunha, Eduardo B. Prata and Leandro M. Gomiero. We also thank DAAE (Departamento Autônomo de Água e Esgoto) for logistic support and to Jaime Somera for the A. lacustris illustration.

\section{References}

AGOSTINHO, AA. et al., 1992. Manejo de recursos pesqueiros em reservatórios. In: Situação Atual e Perspectivas da ictiologia no Brasil. Nupelia, Maringá PR: EDUEM, p. 106-121. (Documento do IX EBI).

ALMEIDA, VLL., HAHN, NS. and VAZZOLER, AEAM., 1997. Feeding patterns in five predatory fishes of the high Paraná river floodplain (PR, Brazil). Ecology of Freshwater Fish, vol. 6, no. 3, p. 123-133.

BARBIERI, G., VERANI, JR. and BARBIERI, MC., 1982. Dinâmica quantitativa da nutrição de Hoplias malabaricus (Bloch, 1974), na Represa do Lobo (Brotas-Itirapina/SP). (Pisces, Erythrinidae). Revista Brasileira de Biologia = Revista Brasileira de Biologia, vol. 42, no. 2, p. 295-302.

BAZZOLI, N. and GODINHO, HP., 1991. R e productive Biology of the Acestrorhynchus lacustris (Reinhardt, 1874) (Pisces: Characidae) from Três Marias Reservoir. Zoologischer Anzeiger, vol. 226, no. 5-6, p. 285-297.

BENNEMANN, ST., ORSI, ML. and SHIBATTA, OA., 1996. Atividade alimentar de espécies de peixe do rio Tibagi, relacionada com o desenvolvimento de gordura e das gônadas. Revista Brasileira de Zoologia, vol. 13, no. 2, p. 501-512.

CATELlA, AC. and TORRES, GE., 1984. Observações sobre o espectro e estratégias alimentares do peixe-cachorro Acestrorhynchus lacustris Reinhardt (1874) (Characidae, Acestrorhynchini), no reservatório de três Marias - Rio São Francisco, MG. In Anais do $14^{\circ}$ Seminário Regional de Ecologia de São Carlos. São Carlos: Universidade Federal de São Carlos, p. 103-125

ESTEVES, KE. and PINTO-LÔBO, AV., 2001. Feeding pattern os Salminus maxillosus (Pisces, Characidae) at Cachoeira das Emas, Mogi-Guaçu River (São Paulo state, Southeast Brazil). Revista Brasileira de Biologia, vol. 61, no. 2, p. 267-276. 
FRITZ, E. S. 1974. Total diet comparison in fishes by Spearman rank correlation coefficients. Copeia, Lawrence, no. 1, p. $210-214$.

GOMES, JHC. and VERANI, JR., 2003. Alimentação de espécies de peixes do reservatório de Três Marias. In: GODINHO, HP. and GODINHO, AL. (Eds.). Águas, peixes e pescadores do São Francisco das Minas Gerais. Belo Horizonte: PUC Minas. $468 \mathrm{p}$.

GOULDING, M., CARVALHO, ML., FERREIRA EJC., 1988. Rio Negro, rich life in poor water: Amazonian diversity and food chain ecology as seen through fish communities. The Hague: SPB Academic Publishing, 200p

HAHN, NS., AGOSTINHO, AA. and GOITEIN, R., 1997. Feeding ecology of curvina Plagioscion squasissimus (Heckel, 1840) (Osteichthyes, Perciformes) in the Itaipu Reservoir and Porto Rico floodplain. Acta Limnologia Brasileira, vol. 9, p. 11-22.

HAHN, NS., DELARIVA, RL. and LOUREIRO, VE., 2000. Feeding of Acestrorhynchus lacustris (Characidae): A Post Impoundment Studies on Itaipu Reservoir, Upper Paraná River, PR. Brazilian Archives of Biology and Technology, vol. 43, no. 2, p. 207-213.

HYSLOP, E.J. 1980. Stomach content analysis: a review of methods and their applications. Journal of Fish Biology, Southampton, vol. 17, no. 4, p. 411-429.

LIMA Jr, SE. and GOITEIN, R., 2001. A new method for the analysis of fish stomach contents. Acta Scientiarum, vol. 23, no. 2, p. 421-424.

MACHADO-ALLISON, A. 1990. Ecologia de los peces de las áreas iniundables de los Ilanos de Venezuela. Interciência, vol. 15 , no. 6 , p. $411-423$.

MENEZES, NA., 1992. Redefinição taxonômica das espécies de Acestrorhynchus do grupo lacustris com a descrição de uma nova espécie (Osteichthyes, Characiformes, Characidae). Comunicações do Museu de Ciências PUCRS, Série Zoologia, vol. 5 , no. 5 , p. 39-54.
MESQUIATTI, AJ., 1995. Alimentação da comunidade de peixes de uma lagoa marginal do rio Mogi-Guaçu, SP. Acta Limnologica Brasiliensia, vol. 7, p. 115-137.

NIKOLSKII, GV., 1963. The ecology of fish. London: Acad. Press. T. F. H. Publications, Inc. 352p.

POMPEU, PS. and GODINHO, HP., 2003. Dieta e estrutura trófica das comunidades de peixes de três lagoas marginais do médio São Francisco. In: GODINHO, HP. and GODINHO, AL. (Eds.) Águas, peixes e pescadores do São Francisco das Minas Gerais. Belo Horizonte: PUC minas, 468p.

POPOVA, OA., 1978. The role of predaceous fish in ecosystems. In: GERKING, SD. (Ed.). Ecology of freshwater fish production. Oxford: Blackwell Scientific Publications, p. 215-249.

SABINO, J. and CASTRO, RM., 1998. Alimentação, período de atividade e distribuição espacial dos peixes de um riacho da floresta atlântica (Sudeste do Brasil). Revista Brasileira de Zoologia, vol. 50, no. 1, p. 23-36.

SAZIMA, I. and CARAMASCHI, EP., 1989. Comportamento alimentar de duas espécies de Curimata, sintópicas no Pantanal do Mato Grosso (Osteichthyes, Characiformes). Revista Brasileira de Biologia = Brazilian Journal of Biology, vol. 49, no. 2, p. 325-333.

SIMON, N., 1983. Predactors and prey. London: J. M. Dent \& Sons. $46 \mathrm{p}$.

UIEDA, VS., 1984. Ocorrência e distribuição dos peixes em um riacho de água doce. Revista Brasileira de Biologia $=$ Brazilian Journal of Biology, vol. 44, no. 2, p. 203-213.

WINEMILLER, KO., 1989. Ontogenetic diet shifts and resource partitioning among piscivorous fishes in the Venezuelan ilanos. Environmental Biology of Fishes, vol. 26, no. 3, p. 177-199.

WOOTTON, RJ., 1992. Fish ecology. New York: Ed. Chapman \& Hall, 212p.

ZAR, JH., 1999. Bioestatistical analysis. New Jersey: Prentice Hall, 929p.

ZAVALA-CAMIN, LA., 1996. Introdução aos estudos sobre alimentação natural em peixes. Maringá: EDUEM/Nupelia, $129 \mathrm{p}$. 